Trout Lake in the collections of the Royal Ontario Museum (pers. corres., R. L. Peterson). The mole has undoubtedly been a part of the fauna of Island Lake for many years because the local Indians have a name for it"onanapajenikäs"-and look upon it as an omen of bad luck, a sign of the death of someone close.

The Star-nosed Mole is rather rare in Manitoba and there are few authentic records or existing specimens. In western Manitoba it is often confused with the Northern Pocket Gopher which is locally called "mole." Records and reports are summarized opposite and shown on the accompanying map.

\section{LITERATURE CITED}

Green, H. U. 1932. Mammals of the Riding Mountain National Park. Can. Field-Nat. $46: 149-152$.

Jackson, V. W. 1934. A manual of vertebrates of Manitoba. Winnipeg. University of Manitoba.

Seton, E. T. 1909. Fauna of Manitoba. British Association Handbook.

Soper, J. D. 1946. Mammals of the northern Great Plains along the International boundary in Canada. Jour. Mamm. $27: 127-153$.

Soper, J. D. 1961. The mammals of Manitoba. Canadian Wildlife Serv., Wildlife Mgt. Bull., ser. $1,17: 1-51$.

Sutton, R. W. 1961. Manitoba's only true mole. "Wildlife Notebook." Winnipeg Free Press, April 1.

Sutton, R. W. 1963. A pocket gopher - alive. "Wildlife Notebook." Winnipeg Free Press, March 9.

\title{
SOME OBSERVATIONS ON CAPTIVE ERMINE
}

\section{by Stuart L. Iverson and Brian N. Turner, Whiteshell Nuclear Research Establishment, Pinawa, Manitoba}

A by-product of an extensive livetrapping study of the Meadow Vole (Microtus pennsylvanicus) at Pinawa has been the occasional capture of an Ermine (Mustela erminea), one of the voles' chief predators. Although many of those captured die of hunger or confinement in the traps (which are designed for mice), some are alive when the traps are checked. Since February 1968, we have been observing this interesting weasel in captivity, with thoughts of learning more about its little-known biology. Since we have only a few Ermine in our cages at any time, we have a good opportunity to observe their habits. The following observations and photographs are based on about two dozen Ermine that have been in our colony for varying lengths of time.

Ermine are remarkably adaptable. After less than two days of living in a glass-walled cage, our first live one, (Stanley, a full-grown male), appeared quite at home and relaxed in his new surroundings. He rapidly took to drinking water from a vertical tube, and made a cosy-looking nest out of packing material. He has now lived in captivity for over a year. This is in direct contrast to the neurotic behaviour patterns developed by many mammals in captivity. For example, tree squirrels often panic when caged and may die of fright, large carnivores can be seen in most zoos pacing back and forth or running in circles, and many rodents, particularly Deer Mice, develop a repetitive somersaulting pattern.

Stanley's curiosity however, was still strong, and any scratching or tapping nearby would bring a head and neck and a pair of bright eyes peering out of his nest. Eventually his curiosity dulled somewhat, and he apparently realized that if there was food coming, it would appear regardless of his reaction to noises near his cage. Quart paint cans lying on their sides with an entrance hole cut in the bottom, and with the lid secured, have now been provided for nest sites. All of our weasels now live in the cans with their heads usually just inside or slightly outside the entrance, allowing them to keep an eye on the world surrounding them.

Although people have been able to handle weasels as pets, this relationship requires long hours of patience, 


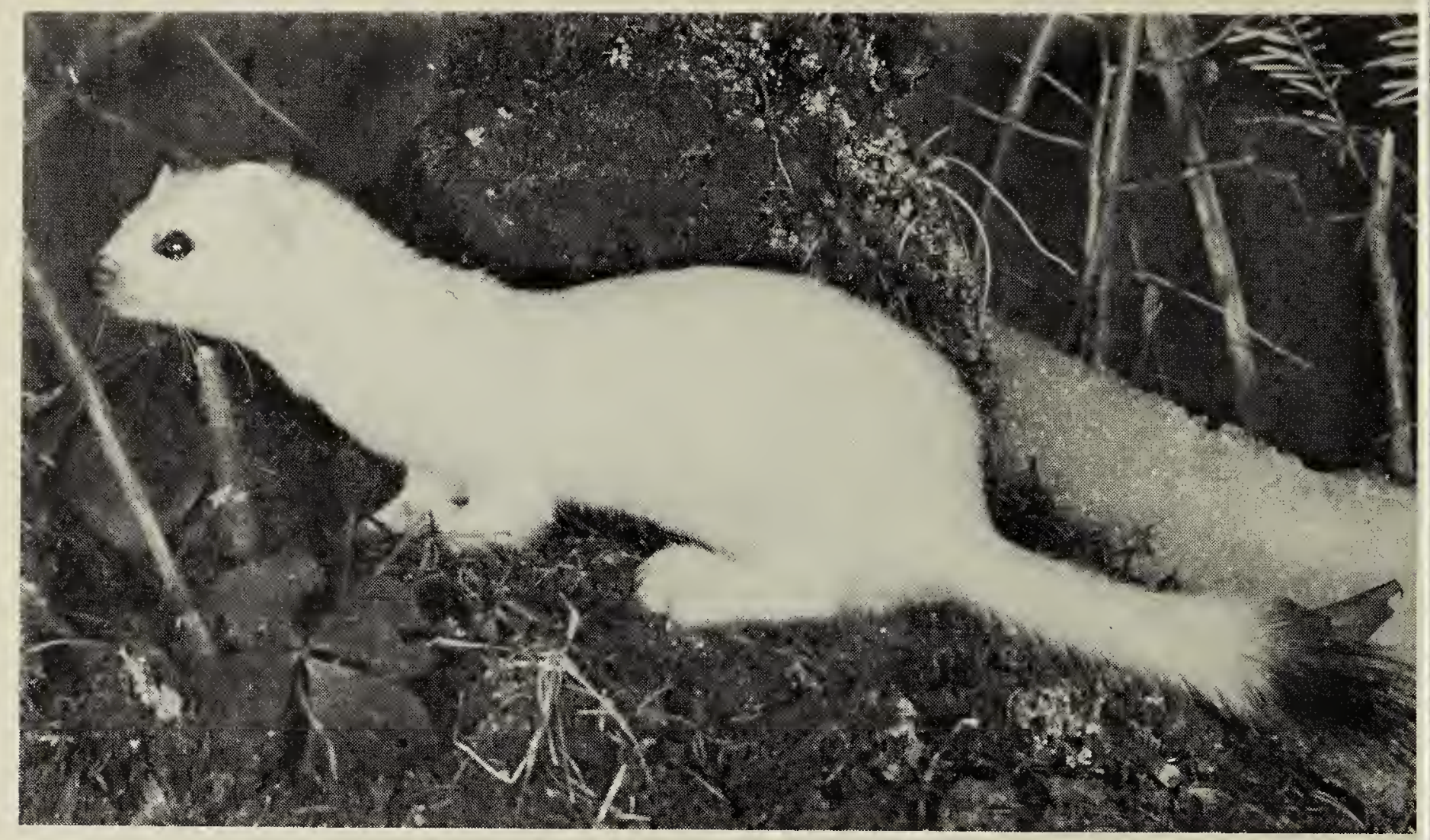

Male Ermine in full winter pelage. Only the tail tip, tip of the nose, the eyes, and a few "whiskers" or vibrissae remain black. The expanded tail tip of the Ermine on the cover indicates a state of excitement (angry or frightened).

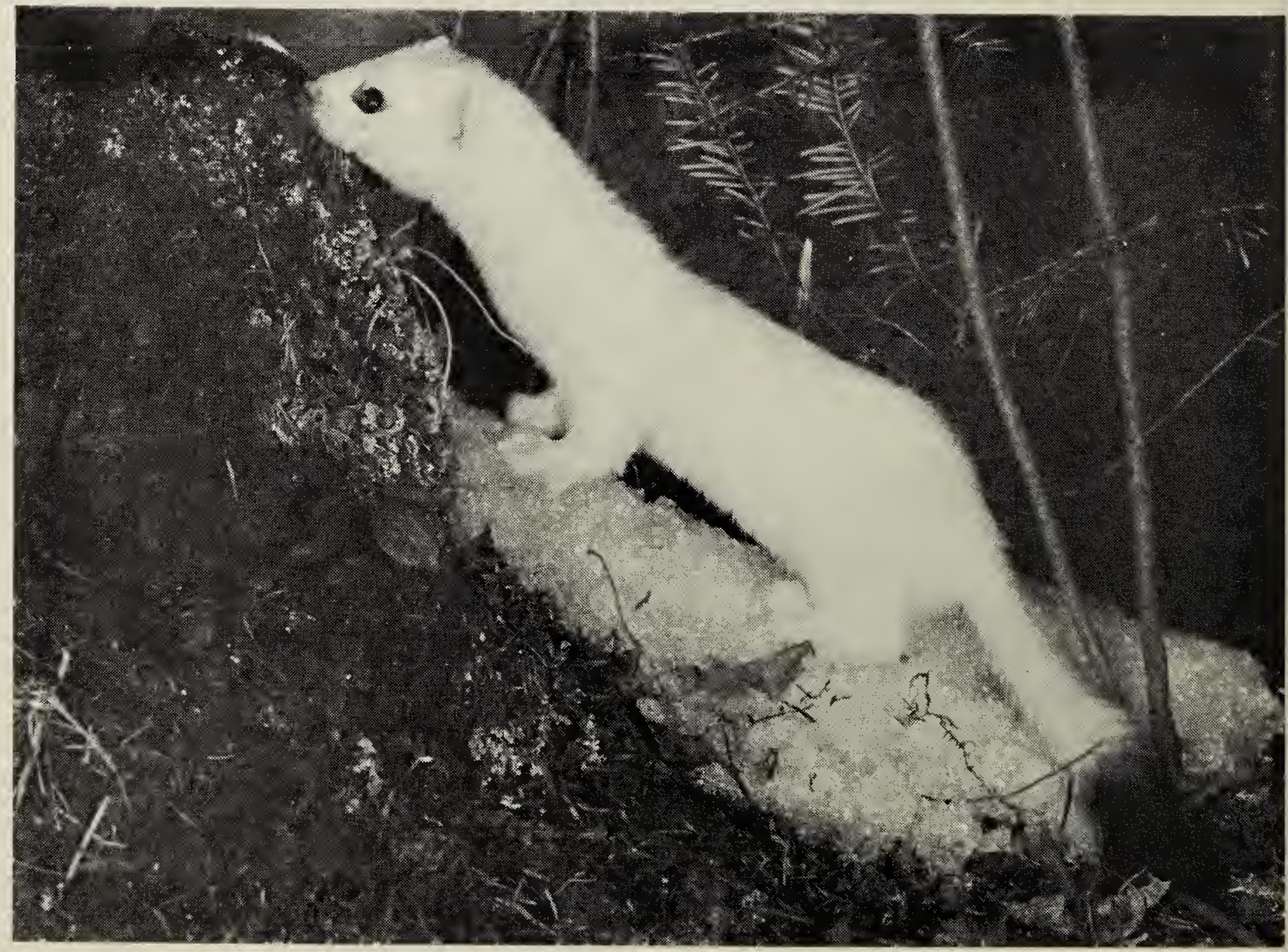

Ermine. Note the elongated body and neck of this small carnivore. The relatively large feet are particularly noticeable in the winter when the paws are covered with thick hair, presumably an adaptation for "snowshoeing." 


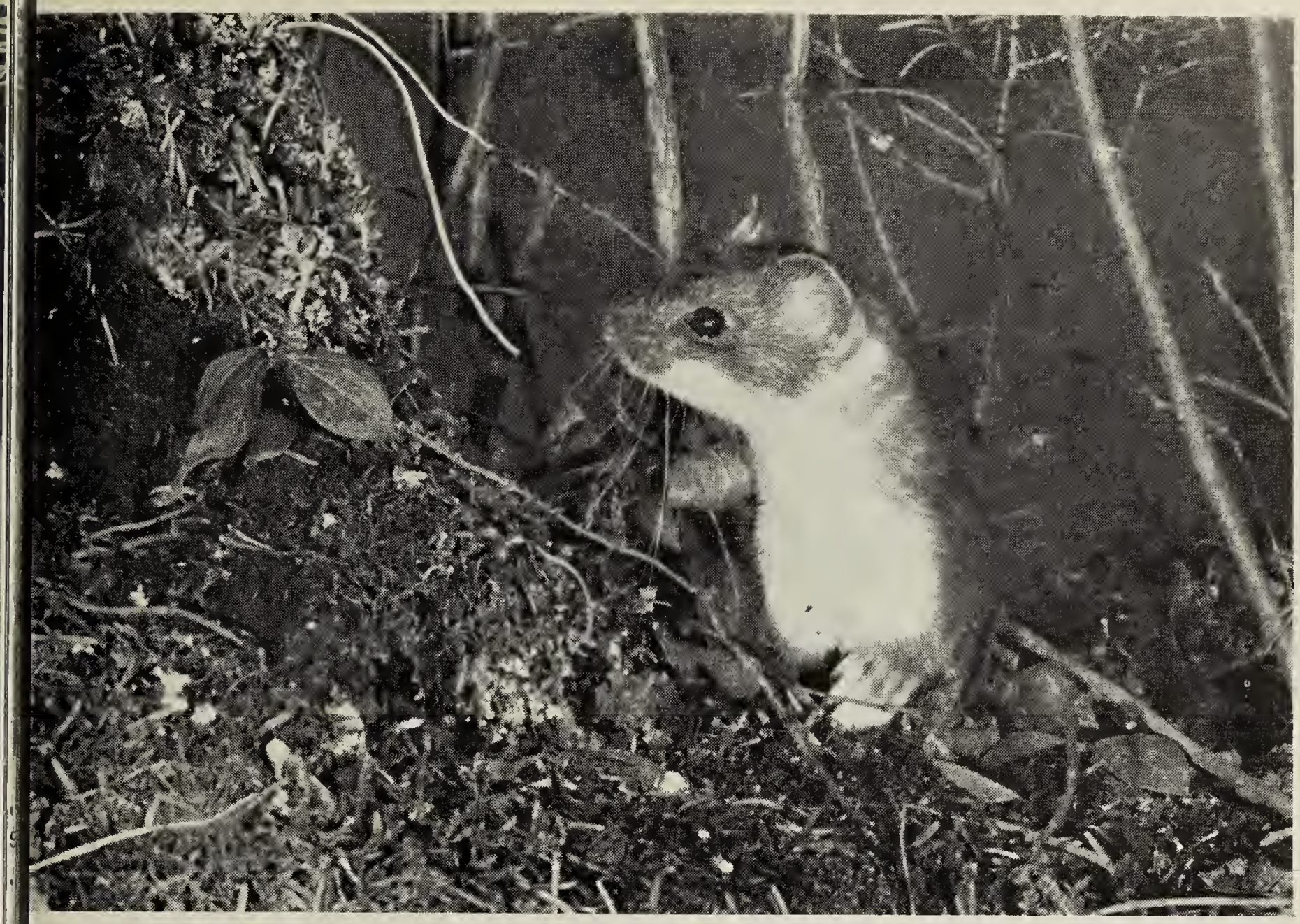

Male Ermine in summer pelage. The tail tip and some vibrissae remain black. The underparts stay white, but the back and sides turn brown. Note the large circular ears.

and with a number of weasels in captivity, the time involved is prohibitive. We thus decided to clean cages by what we thought to be a fairly ingenious system: simply capture the animal in a wire mesh trap, weight it while the cage was being cleaned, and release it back into the cleaned cage. For the first few weekly cage changes, the curiosity aroused by the trap promptly led the weasel to be caught. Later, however, it required more time to coax it into the trap. Stanley long ago refused to leave his cage voluntarily, but instead lay patiently outside the trap entrance, completely frustrating the outwitted trappers. He must now be herded with a piece of cardboard until the only place left to go is into the trap. This old male is probably the tamest of the colony. Although he repeatedly has had the opportunity to bite us, he has only done so once, and then only a token bite which did not break the skin. Stanley apparently would rather try to outsmart his hopeful captor by burrowing through the sawdust under the cardboard, or leaping over the top of it.

Occasionally, one of the weasels becomes disturbed or excited during the capture attempts, and shows its displeasure by erecting the hairs on the tail tuft, and vocalizing. Depending on the degree of irritation, sound varies from a gentle "k-sss" (one of the males, Livingstone, invariably answers this call when given by either of us) to an emphatic chirp. The latter sound is often accompanied by release of the distinctive scent carried in glands in the anal region. Although not really unpleasant, the scent gives a good indication of the Ermine's emotional state, and warns that it should be handled more warily.

Weasels, because of their role in nature, must necessarily be quick and efficient, for a mouse missed by the first strike may be gone in a flash. At first, not knowing what foods 


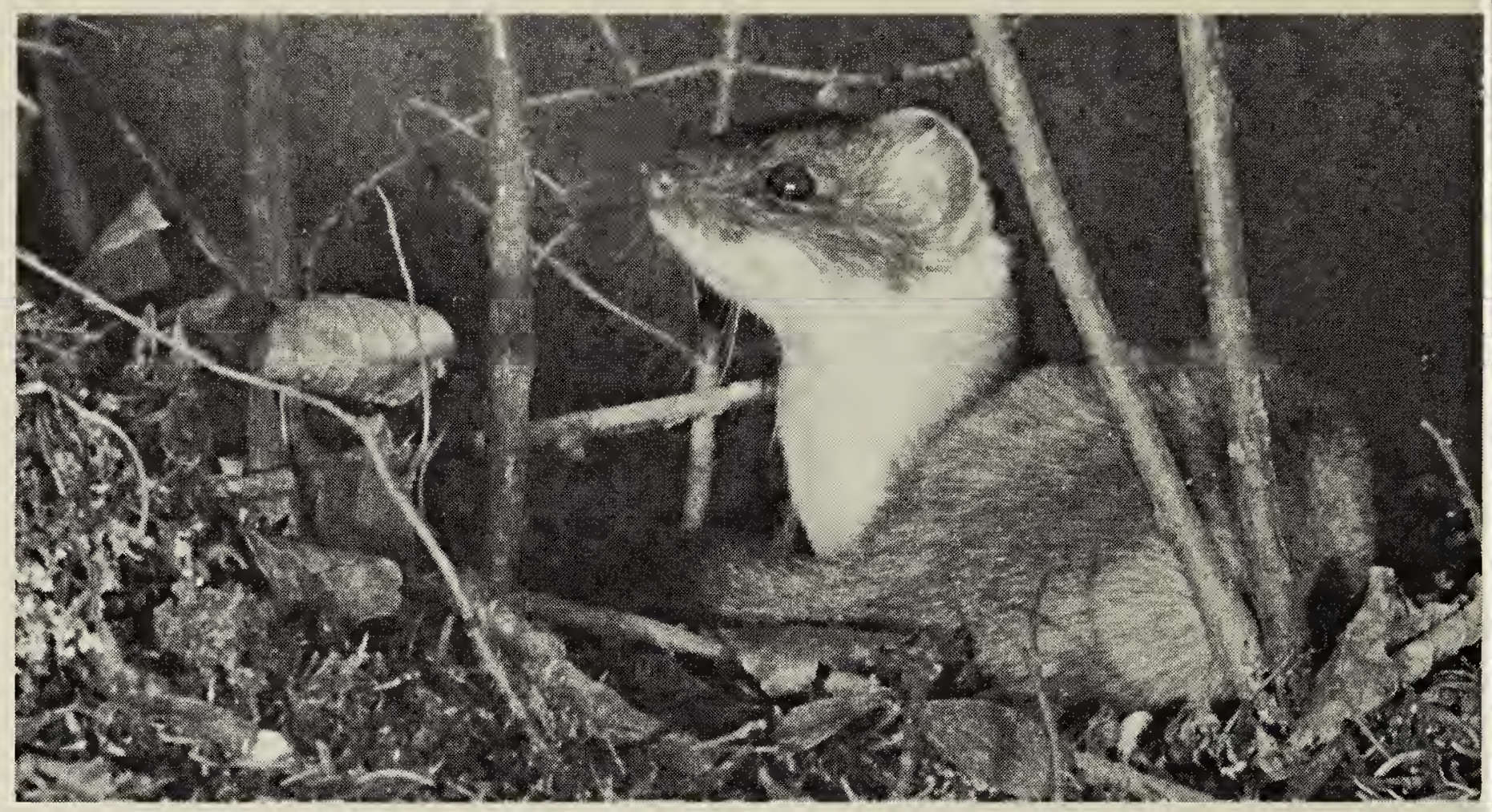

Photos by Iverson and Turner

Ermine. Note how well the animal has adjusted to its surroundings.

Though relaxed and lying down it retains its alertness.

might keep weasels alive in captivity, we fed Stanley a natural diet of live mice. The weasel reacted as expected and with a single strike killed his prey. (Females, one-third to one-half the weight of males, usually have more of a struggle before overcoming their prey). However, we found that many sorts of meat would suffice for food, and the colony is now normally maintained on daily portions of frozen meat. But upon introducing a live mouse to Stanley after several months of this diet, we found he had lost the sharpness for killing prey, and lay puzzled in his nest, watching and sniffing at his new cage-mate. Not surprisingly, after several days of live mice, he soon regained his previous efficiency, and after rapidly dispatching the mouse offered, now looks around as if he expects further ones to be handed in.

To photograph Ermine, we devised an 18 by 24 inch platform supporting a piece of natural habitat on which to place the subject. We were apprehensive of the weasel's reaction to this situation, since it was the least confined area the weasel had experienced since its capture, months previously. Would it leap blindly off the edge?
Would it immediately try to hide? Would the electronic flash affect it? We could have predicted accurately from our past experiences with them. To explore this new area thoroughly was its first reaction, and unless it could clearly see an attainable target, it would not leap off the platform. The flash seemed not to disturb the animals at all, and one of the older males would continuously pose, delighting us and leading to the results seen here.

Our year of close acquaintance with captive Ermine has given us an opportunity to begin to understand the qualities that make them a successful small predator. Their intelligence, curiosity and adaptability enable them to utilize a food source that must be searched for, approached and captured. Their apparent lack of fear, which causes them to approach novel stimuli rather than to flee as do many small mammals, is also a quality useful to a predator. But bloodthirstiness, a trait commonly ascribed to them, is one that we have not observed. Rather, we have found them to be no more "vicious" than plant eaters, merely doing what is necessary for them to live. 